\title{
David Oliver: Pensions policy and public relations
}

\author{
David Oliver consultant in geriatrics and acute general medicine
}

Berkshire

Changes to pension tax rules for doctors have hit the news in recent months. In particular, changes to the lifetime allowance (LTA) for pension pots and the annual allowance (AA) for total annual contributions have caused consternation. ${ }^{12}$

The mainstream media have covered this issue, and Josephine Cumbo, pensions correspondent for the Financial Times, has written extensively about it. ${ }^{3-5}$ It was also raised in Money Box on BBC Radio $4^{6}$ and in a Westminster Hall debate. ${ }^{7}$ But the Treasury has said that senior NHS workers will not be exempt and that reducing pension tax relief for high earners is progressive and fair. ${ }^{8}$

These changes were designed to prevent high earners in the private sector from using large pension payments to reduce their tax bills. But NHS doctors have no control over the size of their own or their employers' pension contribution or their total "adjusted income," short of working fewer hours or leaving the pension scheme altogether. And the last thing we need, at a time of workforce gaps and worsening performance indicators, is senior doctors significantly reducing their sessions. ${ }^{9}$

These changes, and the shock for doctors receiving large and unexpected one-off tax bills, have caused fear, bewilderment, and anger. Five figure sums have been reported—often a large percentage of annual net income, to be repeated yearly. ${ }^{10}$ The NHS pension scheme's own figures show that the LTA changes since 2016 have been a factor for half of the GPs and a third of the hospital doctors who have taken early retirement. ${ }^{11}$ And Jackie Doyle-Price, health minister, acknowledged in the Westminster Hall debate that the policy was harming retention of NHS doctors and causing them to drop extra clinical sessions. ${ }^{12}$

This isn't coherent, joined-up public policy, and this will become apparent when services struggle and senior doctors take years to replace. To resolve these issues, unions and lobbyists need to work behind the scenes, using pragmatic, dispassionate arguments based on the impact of the changes on patient care and the workforce.

They also need some attainable solutions, such as scrapping the tapered allowance, making it less punitive to use a "scheme pays" process ${ }^{13}$ (where the tax bill is deducted from the total pension pot but currently with big accrued interest), enabling automatic voluntary entry for "scheme pays" (rather than requiring annual applications), or having either an AA or an LTA but not both.

In the court of public opinion, we'll have to play things carefully. The public and some sections of the press may not be sympathetic to complaints about tax on pensions from people who earn six figure salaries and have increasingly rare defined benefit pension arrangements that seem generous to most sectors. The comments below Cumbo's pieces include, "I wish I had high class problems like that," and "These are intelligent people-why didn't they plan?" In more mainstream outlets we could easily see a narrative about greedy doctors, gold plated pensions, and the gravy train, with the government shifting blame on to the profession.

Rather than making it just about doctors, we should seek solidarity with other senior public sector professionals affected by these changes, such as NHS managers, head teachers, civil servants, local government workers, and police officers. We need clear, punchy explanations of what is a complex problem, focusing on the impact it will have on services. And we need to handle this issue with care.

Competing interests: See www.bmj.com/about-bmj/freelance-contributors. Provenance and peer review: Commissioned; not externally peer reviewed.

1 BMA. BMA responds to Sunday Times article on pension arrangements and tax charges for consultants. 10 Mar 2019. https://www.bma.org.uk/news/media-centre/press-releases/ 2019/march/bma-responds-to-sunday-times-article-on-pension-arrangements-and-taxcharges-for-consultants.

2 Armstrong S. Cuts to pension tax relief deepen retention crisis for senior doctors. BMJ 2019;364:I20610.1136/bmj.l206

3 Diagnosing the NHS pensions problem. Financial Times 2019 Mar 28. https://www.ft.com/ content/225fb300-4c8e-11e9-bbc9-6917dce3dc62.

4 Cuts to UK pension tax breaks drive NHS doctors to retire early. Financial Times 2019 Apr 2. https://www.ft.com/content/29278318-554c-11e9-91f9-b6515a54c5b1.

5 NHS consultants are turning down shifts over pension bill fears. Financial Times 2019 Mar 25. https://www.ft.com/content/730f1b5a-4fof-11e9-b401-8d9ef1626294.

6 Forces Pension Society. BBC Radio 4's Money Box-NHS pensions and annual allowance. 1 Apr 2019. https://forcespensionsociety.org/news/bbc4s-moneybox-programme-coversthe-annual-allowance-charge/.

7 House of Commons Hansard. NHS pension scheme: tapered annual allowance. 2 Ap 2019. https://hansard.parliament.uk/commons/2019-04-02/debates/71E9792B-AD444938-9A2A-4A4E253D17BE/NHSPensionSchemeTaperedAnnualAllowance.

8 Espadinha M. Govt rules out pension tax exemption for doctors. FT Adviser 2019 Apr 2. https://www.ftadviser.com/pensions/2019/04/02/govt-rules-out-pension-tax-exemptionfor-doctors/. 
9 lacobucci G. Workforce crisis: "punitive" cuts to pension tax relief must be reversed, say consultants. BMJ 2019;364:1977. 10.1136/bmj.1977 30824411

10 BMA. Annual allowance examples. 8 Mar 2019. https://www.bma.org.uk/advice/ employment/pensions/annual-allowance-examples.

11 Moberly T. More hospital doctors are opting to retire early. BMJ 2018;362:k3744. https:/ /www.bmj.com/content/362/bmj.k3744. 10.1136/bmj.k3744 30181157

12 Collins A. Government admits pensions policy a "disincentive" to take on extra work

Health Serv J 2019. https://www.hsj.co.uk/workforce/government-admits-pensions-policya-disincentive-to-take-on-extra-work/7024794.article.
13 NHS Business Services Authority. NHS pensions-annual allowance-scheme pays facility for transition members. 2018. https://www.nhsbsa.nhs.uk/sites/default/files/201801/Annual\%20Allowance-Scheme\%20Pays\%20facililty\%20for\%20transition\%20members20180119-\%28V4\%29.pdf.

Published by the BMJ Publishing Group Limited. For permission to use (where not already granted under a licence) please go to http://group.bmj.com/group/rights-licensing/ permissions 